\title{
CONSTITUTION OF THE \\ INTERNATIONAL ASSOCIATION FOR LEARNING LABORATORIES
}

Original Constitution:

First Revision:

Second Revision:

Third Revision:

Journal, Vol. 10, No. 1)

Fourth Revision:

Fifth Revision:
1964

February, 1966

June 16, 1969

June 18, 1974 (Reprinted in NALLD

March 15, 1977 (NALLD Journal, Vol. 10, Nos. 3-4)

November 28, 1981 (NALLD Journal, Vol. 16, No. 2)

Section 1: Name. The name of this self-governing organization is the International Association for Learning Laboratories, hereinafter referred to as IALL.

Section 2: Purpose. IALL is a professional nonprofit membership organization working towards the goal of improving instruction through the use of technology. Its purpose is to promote more effective use and a better understanding of "mediated instruction" in learning laboratory/resource centers at all levels of education and training.

Section 3: Membership. Any person or organization interested in the purposes and objectives of IALL may become a member upon payment of membership fees as provided for in the Bylaws for classes of membership as the Council may from time to time establish.

\section{ARTICLE II. Governance and Officers}

Section 1: Governance. The determination of policy and the direction of affairs of IALL are the responsibility of an Executive Board and a Council elected or appointed and functioning as provided herein and in the Bylaws. Every member of the Executive Board and Council must be a member in good standing of IALL.

Section 2: $\quad$ Elected Officers. The elected officers of IALL shall be a President, a President-Elect, a Secretary, and a Treasurer. These officers shall be elected and serve terms as provided for in the Bylaws. The officers shall hold office until their successors are elected and qualify.

Section 3: $\quad$ Executive Director: An Executive Director shall be appointed by the Executive Board with the approval of the Council as provided for in the Bylaws. The Executive Board may terminate the services of the Executive Director upon giving three months notice. 
He shall be appointed for a term not to exceed two years and may be reappointed.

Section 4: Vice President. The position of Vice President shall be appointed by the Executive Board with the approval of the Council as provided for in the Bylaws. The Vice President will be a representative of one of the commercial or institutional members of IALL. He shall be appointed for a term not to exceed two years and may be reappointed.

Section 5: Additional Officers. Additional officers shall be appointed by the Executive Board to include a Journal Editor, Advertising Manager, Director of Publications Center and other officers as provided for

in the Bylaws. Unless otherwise specified in the

Bylaws, their appointments will generally be for a term not to exceed two years, although they may be reappointed.

Section 6: Executive Board. The Executive Board shall consist of the President, President-Elect, Secretary, Treasurer, and Executive Director.

Section 7: Council. The Council shall consist of members of the Executive Board, Vice President, Immediate Past President, Journal Editor, Advertising Manager, Director of Publications Center, Regional Chapter Presidents, Chairmen of Standing Committees, and others as may be identified in the Bylaws.

Section 8: Elections. The elected officers of IALL shall be elected by the membership of the association for terms specified in the Bylaws.

(a) The President shall be the person elected as President-Elect by the membership from the prior election. In the event that the President shall not serve out the full term, the President-Elect shall succeed to the unexpired remainder of the term and continue through his own term.

(b) The President-Elect, Secretary, and Treasurer shall be elected by the membership. In the event that the President-Elect shall be unable to serve out the term, both a President and a President-Elect shall be nominated and elected at the time of the next election. Where a vacancy appears on the Executive Board, other than President, the Council shall elect a member to fill the remainder of the unexpired term of that officer, upon the recommendation of the President. In the event that both the President and the President-Elect shall be unable to serve, the Council shall elect one of its members to serve as the presiding officer of IALL.

(c) The members of the Executive Board and Council 
Section 9:

Section 10:

Section 11: Publication of Constitution and Bylaws. The Constitution and Bylaws shall be reviewed periodically by the Executive Board, and published and distributed to the membership.

\section{ARTICLE III. Amendments}

Section 1: $\quad$ Proposals from the Executive Board and Council. Proposals for amending the Constitution which receive a majority vote of the Council, and with the Executive Board's recommendation, shall be submitted to a vote by the membership.

Section 2: Proposals from the Membership. Proposals for amending the Constitution may be submitted to the Executive Director by a petition signed by five percent of active members of IALL. After validating 
the signatures on the petition, the Executive Director will take the necessary steps to present the proposed amendment to a written ballot vote by the membership.

Section 3: Effective Date. An amendment to the Constitution shall become effective when it has been approved by no less than two-thirds of the ballots returned to and counted by the Executive Director.

Section 4: Amendments to Bylaws. Specific procedures, regulations, and guidelines for the association shall be established in the Bylaws under the direction of the Council. The Bylaws and amendments to the Bylaws shall become effective when they are approved by a majority vote of the Council. Revisions to the Bylaws should be made known to the membership from time to time.

The fifth revision of the Constitution became effective at the close of the annual NALLD Business Meeting on Saturday, November 28, 1981, held at the ACTFL Conference. It received a majority vote of the membership of the ballot returned prior to the meeting and by those present at the meeting.

\section{Moni-Com III Wireless Language Laboratory An all-new system from the leader}

This third generation system-the exciting Moni-Com Ill language lab-now features solid state microelectronics to use less energy, take up less space... and it even costs less than before!

Turns any room

into $\mathbf{a}$ lab

Simple loop antenna installs easily. Twoway wireless headset/transceivers (with boom mics) allow unrestricted room usage and student positioning within the room.

\section{Level III lab \\ now wireless}

The new P/H Portable Drill Recorder permits individual, dual track student recording so they can listen, respond and compare.

For literature or a dramatic, no-obligation demonstration, contact:
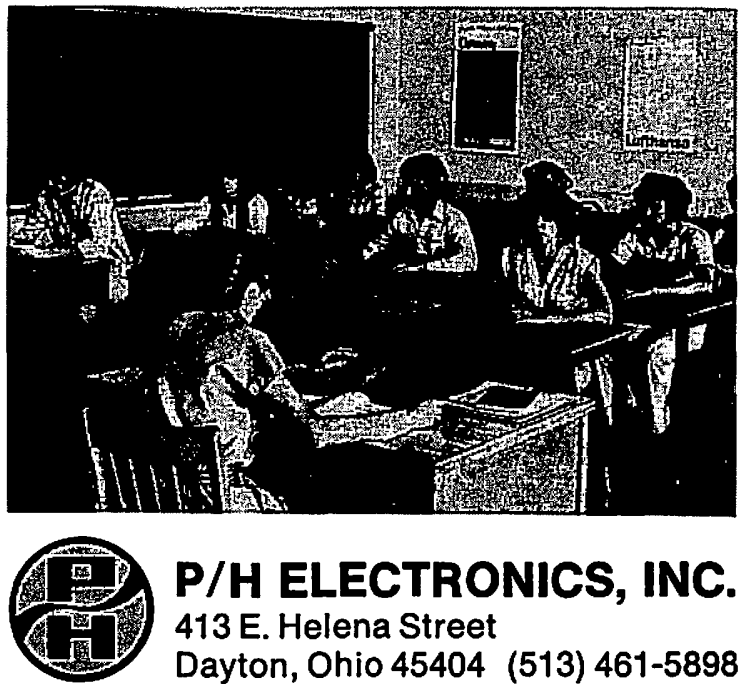

P/H ELECTRONICS, INC. 413 E. Helena Street

Dayton, Ohio 45404 (513) 461-5898 
JALT is. . .

An organization of professionals dedicated to the improvement of language learning and teaching in Japan.

A vehicle for the exchange of new ideas and techniques in TEFL/TESL, Japanese as a Second Language, etc.

A means of keeping abreast of new developments in a rapidly changing field.

A resource center for information on job opportunities and study programs both in Japan and abroad.

\section{ACTIVITIES}

- JALT JOURNAL - An annual publication

- JALT NEWSLETTER - A 20-28 page monthly publication

- JALT INTERNATIONAL CONFERENCE ON LANGUAGE TEACHING/LEARNING - The 1982 conference is scheduled for October 9.1 1 at Tezukayama Gakuin University, Sayamacho, Osaka. The deadline for abstract submissions is June 30, 1982. Contact the Executive Secretary for further details.

- LOCAL CHAPTERS - II Chapters span the nation from Sapporo, Hokkaido in the north to Naha, Okinawa in the south. Each organizes monthly/bi-monthly meetings usually free to regular and student members. Overseas memberships may be converted to regular chapter memberships upon arrival in Japan.

* RESEARCH \& MATERIAL DEVELOPMENT GRANTS - Awarded annually. Application must be made to the President by September Ist of each year.

APPLICATION

Applications should be sent with a check or money order in yen or U.S. dollars to:

Thomas N. Robb

Executive Sec'y, JALT

Kyoto Sangyo University,

Dept. of Foreign Languages

Kita-ku, Kyoto 603

JAPAN

\section{MEMBERSHIP FEES}

Student Membership

Regular Membership

Regular Joint Membership

Overseas Membership

Overseas Joint Membership

Commercial Membership

Institutional/Library Subscription

Overseas Airmail Surcharge:
$¥ 3000 / 515$

$¥ 5000 / 525$

$¥ 8000 / \$ 40$

$¥ 5000 / 525$

$\because 6000 / 530$

$¥ 50000 / 5250$

$¥ 5000 / \$ 25$

$¥ 3000 / 515$

THE JAPAN ASSOCIATION OF LANGUAGE TEACHERS

NAME:

DATE:

MAILING ADDRESS:

Amount:

HOME PHONE:

Menbership Type Applied For

Student Regulat 员 Individus

SCHOOL/COMPANY NAME:

Oversezs O Institutional/hibrasy Commetcial

Please check both the primary kind of teaching you do and the primary language you teach, and any secondary areas ss well:
向 Pre-setookers
미 Ekemeatary School
12
Sr. Hiten School
ด้
Commercisl Lenguage School
' 2
प्र Ji. High School
미 Prep School/Juku
미
Company Program
Dxchange Program
DO Private Clesses
Gov't./Research Instituse
口D Other

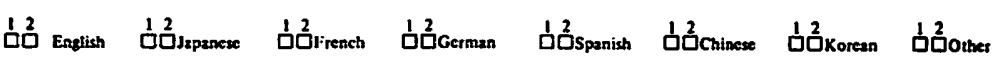

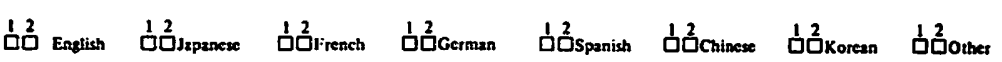

